\title{
ANALYSING POLICY FOR INCLUSIVE INNOVATION: THE MOBILE SECTOR AND BASE-OF-THE-PYRAMID MARKETS IN KENYA
}

\author{
Christopher Foster \& Richard Heeks* \\ Centre for Development Informatics, University of Manchester, UK
}

\begin{abstract}
Recent interest in inclusive innovation to serve base-of-the-pyramid markets has so far produced relatively little evidence about the role of policy. Drawing on cases from Kenya's mobile phone sector that have successfully scaled innovations to poor consumers, we suggest that policy making is not only present, but can have a significant role in shaping and supporting inclusive innovation systems.
\end{abstract}

In these cases, inclusive innovation has been built upon a reinforcing circle of adaptive innovation, dynamic competition, and presence of innovation intermediaries within poor communities. Following regulatory interventions that helped initiate these markets, policy has supported the facilitators of inclusive innovation in various ways. But implementation gaps can dampen innovation or allow it to proceed in directions that undermine quality.

Overall, this paper offers a systematic approach for analysing the role of policy in inclusive innovation, an example of the multiple domains that must be integrated if inclusive innovation is to be purposely supported, and evidence that the implementation of such policies matters as much as their content.

Keywords: Inclusive Innovation; Innovation Policy; Systems of Innovation; Base-of-thePyramid; Mobile; Kenya

\footnotetext{
*Corresponding Author: Prof. Richard Heeks, Centre for Development Informatics, IDPM, University of Manchester, Arthur Lewis Building, Manchester, M13 9PL, UK richard.heeks@manchester.ac.uk
}

\section{Paper subsequently published in Innovation and Development journal: please refer to journal for definitive, final version of paper}




\section{INTRODUCTION}

Inclusive innovation can be seen as having two aspects: inclusivity of process (e.g. the involvement of poor community members in design and development) and inclusivity of output (e.g. the development, production and delivery of goods and services that are appropriate to the development needs of the poor) (Cozzens \& Sutz 2012). While recognising the potential interlinkage between the two aspects, here, our focus is mainly on the latter; looking specifically at the role of government policy in systems that successfully develop and deliver innovative goods and services to very large numbers of poor consumers in developing countries.

There is growing recognition that inclusive innovation - by and for base-of-the-pyramid (BoP) groups - is central to development strategies ( ibid.). This has begun to create a set of re-orientations: for example, arguments about the need to re-orient business strategies (Prahalad 2009) and to revise our understanding of innovation systems (Lundvall et al. 2009). There is also a need to reconsider the role that policy can play in such innovation systems but also an acknowledgement that, to date, relatively little empirical evidence has been gathered on the role of policy in real cases (Altenburg 2009).

To address this issue, we begin by reviewing the rationale for policy in inclusive innovation systems, the areas that generic innovation-relevant policy covers, and specific policy issues that may arise within such systems. Following this review of past literature, we draw on two case studies from the mobile phone sector in Kenya, to investigate policy's role in enabling handsets and mobile services to be developed and delivered to the majority of the population. We link policy to four systemic facilitators: regulatory intervention, adaptive innovation, competitive markets, and intermediaries embedded within poor communities. We also identify the impact of gaps which emerge between policy making and policy implementation.

The paper concludes by reviewing the overall policy map that has been built via the threestage analysis: of key inclusive innovation facilitators; of policies relevant to those facilitators; and of implementation of those policies. 


\section{POLICY, INNOVATION SYSTEMS AND INCLUSIVE INNOVATION}

\subsection{Inclusive innovation systems}

Systems of innovation models seem an appropriate basis on which to found an investigation of policy and inclusive innovation. These models are well known to provide guidance on policy responses to innovation (Edquist 1997, Lundvall 1992). They have traditionally been applied to analyse broad national policy and growth in core industrial sectors; first in industrialised countries and latterly in developing countries. However, these models have also shown relevance to a broader range of sectors and locations (Kraemer-Mbula \& Wamae 2010, Lorentzen \& Mohamed 2009).

In applying systems of innovation models to situations of inclusive innovation, as noted above, some revisions may be needed. Consumer-producer interaction has always been a component in systems of innovation (Edquist \& Hommen 1999). But it comes more to the fore with innovation for poor consumers in developing countries given the very different needs of such groups from "traditional" consumers in the global North, the uncertainties and resource scarcities within such markets, the particular local institutional forces at play, the heterogeneity between local markets, etc (McCormick \& Oyelaran-Oyeyinka 2007, Prahalad 2009, Srinivas \& Sutz 2008).

One upshot is a need for innovation intermediaries who link core innovators with base-of-thepyramid consumers. Such actors are themselves innovators, adapting and "domesticating" innovations both technically and socially so they are appropriate for poor communities (Williams et al. 2005). They may also link the demand side back to the wider innovation system through 'reverse' flows of information and innovation (Arocena \& Sutz 2000, London \& Hart 2004). All this is done not in some front-loaded process of laboratory-based research and development but as an integral, incremental and continuous activity - of "doing, using and interacting" (Lundvall et al. 2009) - that enables the innovation to diffuse to, and be effectively used by, BoP consumers. Hence, the application of the "innofusion" label (Fleck 1993), summarising the inextricability of innovation and diffusion processes when serving such markets.

\subsection{Rationale for policy}

Government policy can be seen as an institutional force that seeks to shape human behaviour, but why is it necessary in inclusive innovation systems? 
In a general sense, the rationale for policy interventions arises when there are failures of some kind within the innovation system (Bergek et al. 2008). These could be regarded as failures of process such as an unclear articulation of market demands, or too great a perception of risk, or an absence of key competencies which lead either to innovation not occurring or to it occurring in insufficient or inefficient or ineffective ways (Edler 2010). Or these can be failures of output such as innovations being produced where the price does not reflect the social cost (e.g. environmental impact), or where the price does not reflect the social value (e.g. placing items outside the reach of BoP consumers).

Such failures may be more likely to arise within inclusive innovation systems where these involve the actors, institutions and needs of base-of-the-pyramid markets on the one hand, and on the other, large institutions - such as multinationals and global supply chains - that have hitherto dealt with more wealthy consumer markets. In the absence of effective intermediaries of the type described above, this can give rise to a type of "systemic fracture" between user and producer that requires policy interventions because it hampers the typical innovation system functions of knowledge diffusion, entrepreneurial experimentation, market formation, etc (Bergek et al. 2008). Policy intervention may be given impetus by developmental agendas which want innovation systems to produce new goods and services for the low-income mass of the population in developing countries (Altenburg 2009).

\subsection{Policy domains for inclusive innovation}

Beyond the question of why policy is needed, policy makers are largely concerned with what policy is needed. As noted, guidance on policy specifically for inclusive innovation has been limited, but we can examine the general policy domains of relevance to innovation.

A central focus has been on supply-side interventions which support research and development within core private and public sector institutions, and processes of learning within production (Lundvall 1992). These might include subsidies or tax breaks, sometimes aimed at specific sectors, or "softer" supply-side actions such as enhancing capacity to adapt and absorb exogenous innovations (Bell \& Pavitt 1993, OECD 2011).

There are also demand-side interventions, which can be direct, such as the use of public sector procurement to drive demand for new goods and services, or financial incentives for diffusion and adoption of innovations in other sectors (ibid.). Less direct actions might include attempts to shape consumption e.g. via standards or labelling, helping articulation of 
demands to potential innovators, and introducing sectoral or other regulations that require innovative responses (Ashford et al. 1985).

Regulation of innovation is a further domain - very much linked to the supply side - seeking to affect the perceived and actual returns to innovation; for example, via intellectual property rights legislation. Finally, innovation is also impacted by more generic policies, such as those which support markets and enterprise. These might be sectoral, such as rules governing market entry/exit for firms or sectoral employment rules; or broader, such as general support for, and regulation of, enterprise (Edquist 1997). Innovation (again mainly on the supply side) is also affected by even more foundational policies, such as those on education and infrastructure.

Beyond these generic policy domains, actual policy will be determined by specific context (Chaminade \& Edquist 2010). We can hypothesise particular features when related to inclusive innovation for BoP consumers: a lesser or different role for traditional innovation institutions, the need to incorporate innovation intermediaries, a lesser role for standards/labelling, etc. But beyond this, we have limited evidence-based guidance of the link between policy and inclusive innovation. So there is much to research here, both in terms of the overall domains of policy to prioritise, and the specific instruments within each domain to apply in particular contexts.

\subsection{Policy making and policy implementation}

Systems of innovation models typically reference policy in connection to formal institutions: overarching rules and regulations that appear within government policy, and which are seen to act on formal organisations such as universities, private firms, research bodies, etc. (Johnson \& Edquist 1995). Implicit here are two related assumptions which could be questionable in any context, but which are especially so in the context of inclusive innovation systems.

The first assumption is that formal institutional forces are what matters in shaping innovative behaviour. Yet we know that informal institutional forces - informal norms, cognitive 'ways of doing things', cultural values (Scott 2001) - are equally important in practice; as seen in reality when policy reaches local markets in developing countries (Berdegué 2005). And following directly from this, we will need to differentiate policy making from policy implementation. It is policy as put into practice (or not put into practice) which matters to 
processes of inclusive innovation, more than policy in theory. That gap may become more marked as one moves away from government and large firms, and towards the BoP consumers within inclusive innovation systems.

\subsection{Summary}

In sum, there is a knowledge gap around policy for inclusive innovation, and that gap can be investigated through a three-step process. First, identifying those factors within the inclusive innovation system which are crucial in determining its success or failure. Second, examining at a macro-level the domains of policy which interact with those factors. Third, analysing at a micro-level any gaps between policy making and implementation, and their implications for the key factors.

\section{INCLUSIVE INNOVATION IN THE MOBILE PHONE SECTOR}

\subsection{Approach}

We draw on case studies within the mobile phone sector, focussing on Kenya to examine the links between policy and inclusive innovation. This sector was chosen because it has seen significant diffusion of innovative goods and services to base-of-the-pyramid markets, involving an explicit role for government policy. Thus it is in line with a sampling approach of taking cases of high 'intensity' in order to maximise the potential of exploratory research at an early stage of understanding a phenomenon (Miles \& Huberman 1994).

Specifically, we examine two sub-sectors: mobile handset supply and mobile money services (cash transfers through mobile phone messaging). These mobile goods and services are both accessible by the majority of the Kenyan population and both have been shaped by policy. They also offer some additive, contrasting features, with mobile handsets predominantly revolving around technology transfer, while mobile money has largely been a locallydeveloped innovation.

Research was undertaken in Kenya during 2010 and 2011, involving in total 109 semistructured interviews with actors in order to understand their role in this inclusive innovation system: policy makers (14 interviews); handset producers (7); handset distributors and wholesalers (20); informal handset sellers (27); mobile money operators and dealers (8); mobile money agents (32); and other demand-side micro-enterprises e.g. phone repairers, 
airtime or accessory retailers $(15)^{1}$. Interviews were typically of thirty minutes to one hour duration with street-level intermediaries (agents, informal sellers, etc) and one to two hours' duration with other actors and policy makers. Data gathering also included extensive document analysis, particularly relating to policy making and implementation of relevance to the two sub-sectors.

In reporting findings, first, we build a historical analysis of the development of these two innovations systems, particularly noting the key phases and turning points and identifying policy (or lack thereof) connected to these elements. Second, we follow the three-part analytical approach just outlined in order to determine: the key factors within the innovation systems, the particular policies that have impacted each factor, and then the realities of policy implementation.

\subsection{The mobile phone sector}

While not completely ubiquitous, the mobile phone sector increasingly reaches low-income groups in Kenya, and is shown to already be having a measurable impact on their livelihoods (World Bank 2010). Mobile handsets have grown in availability. In a 2011 government survey, more than $70 \%$ of the population had access to this innovation (CCK 2012), with an increasingly competitive market of firms attracting less-affluent users. In terms of mobile money, there were roughly 19 million registered subscribers at the end of 2011 transferring around US\$700m per month, the great majority of whom (c.90\%) were registered with MPesa (ibid., Safaricom 2011). Again, research has shown growing adoption and use among less-affluent groups (Jack \& Suri 2010).

To support this increasing penetration of base-of-the-pyramid markets, there has been a significant presence of intermediaries who provide the link between large suppliers and poor consumers. In the mobile handset case, increasing numbers of "semi-formal" actors - such as sellers and repairers - form a channel of delivery that enables initial adoption and ongoing use of the technology by the poor. In late 2011 , there were 48,000 mobile money agents again, the great majority part of the M-Pesa system - who are increasingly embedded in the informal markets and trading areas used by poor communities (CCK 2012, Safaricom 2011). They provide conversion between mobile money e-cash and real cash, and other services such as registration and assistance to customers.

\footnotetext{
${ }^{1} 14$ informal sector interviewees combined two roles out of: informal handset seller, mobile agent, and other demand-side micro-enterprise.
} 
As mentioned in the literature review, and as discussed further below, these may best be labelled "innofusion intermediaries" since they are central to the diffusion of new goods and services to the poor, and also undertake and share minor adaptive innovations in order to facilitate this diffusion. These actors form part of a wider innovation system of stakeholders that, as described above, is inclusive in output terms: ensuring development and delivery of goods and services appropriate to poor consumers, which have had a demonstrable developmental impact in economic and social terms.

\section{A BRIEF HISTORY OF TWO MOBILE INNOVATIONS}

\subsection{Mobile handsets}

In 1998, the Kenya Communications Act was passed. Alongside introduction of new telecommunications regulations and authority, it liberalised mobile telecommunications market entry and operation. Within two years, competing mobile operators were up and running, and the mobile sector began to grow rapidly in the early 2000s. As part of their services, the two licensed mobile operators also began to sell mobile phones from international firms through their stores and partners, typically located in urban areas. Initially such supplies were expensive and soon, the formal stores found themselves in competition with less formal suppliers of mobile phones, particularly long standing goods importers importing through grey market routes. This early stage was one of technology transfer of undifferentiated products. However, while the two mobile operators focused on more affluent urban users, importers increasingly sought wider markets; for example, building supply relationships with micro-entrepreneurs in smaller towns who would sell phones into these areas.

Increasing saturation in markets of the global North during the 2000s made international mobile phone suppliers start to turn their attention to the global South. In East Africa around 2005, growing demand and stronger regional integration via the East African Community made Kenya an attractive location for international mobile phone firms but with increasing focus on localisation and adaptation. In terms of innovation, phone models began to emerge that were more tailored towards the needs and context of poor consumers. This was initially driven by international donor agencies in collaboration with government, and then also seen as part of corporate social responsibility, for example supporting shared phone models in poor communities and development of universal service provisions. As these markets 
commercialised, other adaptations were mainstreamed such as extended battery life and local language interfaces. In terms of the emerging innovation system, the large mobile suppliers were increasingly aware of the competition from less formal importers. The suppliers attempted to link themselves to informal mobile sellers based in BoP communities, hoping to replace the grey-market importers with their own distributors who would work direct with the BoP-based sellers. This "squeezing out" strategy did not work very effectively: relations between informal importers and informal BoP sellers were typically reciprocal, built around trust and contextually-relevant financial models such as small-scale sale-or-return, and crediton-supply. In addition, the importers diversified their offering - bringing in second-hand or adapted Chinese phones - that were cheaper or in other ways more relevant to the needs of poor consumers.

In the Kenyan budget of 2009 - and responding to lobbying from the formal handset suppliers suffering from this price undercutting - the government removed VAT on mobile phones. This resulted in a more level playing field between grey market and official imports, and paved the way for intense competition connected to growth of local mobile brands (GSMA 2011). Local consumers could now buy branded phones of increasing quality at a lower price. For informal phone sellers embedded in BoP markets, the dedicated local distributors of branded phones now became viable suppliers. Their numbers grew with some new sellers or outlets linking into the reliable supply lines of formal, branded phones rather than face the negotiation of difficult, grey-market relationships with importers. However, the importers adapted to this challenge; increasingly building links to sellers in rural areas and building relationships with Chinese phone suppliers, contributing to supplies of yet-cheaper phones more suitable for less affluent groups. While simultaneously fighting this competition, the larger-brand firms also showed evidence of reverse or lateral innovation flows, as they began mirroring BoP-relevant features appearing in the grey market like built-in LED torches and dual-sim handsets.

During 2010 and 2011, a new stage of standardisation began emerging. With large brands increasingly exasperated by the competition from Chinese firms, rhetoric around quality, counterfeiting and criminality was being thrown more and more at the informal channels. In 2008 the Kenyan Anti-Counterfeit Act was brought into law, providing wide ranging (some would argue draconian) powers to raid firms and confiscate equipment with minimal evidence. High-profile raids of importers and sellers were now undertaken in an attempt to 
deter these actors and also the end consumers. Beyond this, the government brought forward plans to allow network blocking of grey-market phones, a controversial change which if instigated might render more than two million mobile phones (around 10\% of the total) unusable in Kenya (CCK 2011).

\subsection{Mobile money (M-Pesa)}

Initially M-Pesa began in 2003 as an innovation pilot mainly focussing on applications for micro-finance organisations. It was instigated with the support of government by a partnership of the UK Department for International Development working with Vodafone Group and their Kenyan subsidiary Safaricom. However, the direction then changed somewhat, with evidence emerging during field trials of the viability of innovations revolving around mobile-enabled e-cash transfers. Safaricom then became the lead firm, and in the early stages of innovation took ideas from the trial to market in the form of M-Pesa, a mobile money transfer service. This process involved interactive partnership between the firm and the state regulator with some adaptation of the service - for example to enable anti-money laundering audit trails - to ensure approval. Once the service was approved, it initially focussed on more affluent urban users, with cash-in/cash-out agents typically being established Safaricom partners.

From early 2008, M-Pesa moved into more aggressive scaling, connected to a number of factors. Growing demand arose partly from network effects: as more users joined, both awareness and utility grew among potential users (Jack \& Suri 2010). In addition, the political crisis in Kenya (in late 2007) led to a more unstable general environment, which further increased the salience and utility of mobile money transfer. Field evidence also suggests that agent partners found themselves able to act more autonomously, and this resulted in service innovation, particularly the development of new types of sub-contracting relations which brought into the innovation system agents embedded in low-income communities. These sub-agents, in turn, began their own innovations - addressing particular local consumer needs; finding new ways to manage their cash "float"; dealing with local crime/security risks - to ensure diffusion and maintenance of this new service to the BoP. Aggressive growth continued after the political crisis connected to the emergence of mobile money competitors. This spurred Safaricom to support the innovations of its agent and subagent intermediaries, with some instances of reverse innovation flows. For example, kiosk 
models, security measures, and forms of sub-contracting developed by intermediaries were absorbed by Safaricom as core approaches.

By the start of 2010, though, Safaricom perceived the growing "innofusion" system to be proliferating rather chaotically, particularly the relationship to sub-contracted agents. It made an attempt at standardisation, seeking to impose a new structure that would both simplify relations and consolidate its own control. But this standardisation also risked extinguishing many of the localised partnerships which were central to use of the service in poor communities. As a result, it was often resisted by existing agents and sub-agents.

In the most recent stage of functional scaling, M-Pesa has looked to grow through a strategy of expanded scope; innovating in order to integrate M-Pesa into wider financial systems and functions in Kenya. This derives in part from Safaricom's goal to maintain or increase average revenue per user. The new phase also connects to a second wave of competition stemming from the government's publication of "agent banking guidelines" in 2010 (CBK 2010). These allowed commercial banks to offer their financial services via agencies, raising the potential for M-Pesa of competition in the field of m-money services ${ }^{2}$.

\subsection{Stage summary: policy and other influences}

The outlines above trace out the history by which two ongoing innovations - mobile phones as a product, and mobile money as a service - have successfully been developed and delivered to a mass, base-of-the-pyramid market. Drawing on those outlines and other fieldwork, Table 1 summarises the stages identifiable for each case and, for each of the stages, the main drivers and the main barriers to stage progression and transition. As discussed further in the following section, although one among a number of factors, policy has been a constant shaper of these inclusive innovation histories.

\footnotetext{
2 Though there has so far been a lack of policy on interoperability between m-money systems. Without this, "from a regulatory perspective, it is apparent that m-banking in developing markets has the potential to tip towards a dominant platform" (Anderson 2010 p.22).
} 


\begin{tabular}{|c|c|c|}
\hline Stage & Drivers of stage & Barriers to transition to next stage \\
\hline \multicolumn{3}{|c|}{ 1) Mobile handset supply } \\
\hline $\begin{array}{l}\text { Technology } \\
\text { transfer }\end{array}$ & $\begin{array}{l}\text { - Establishment of competition and } \\
\text { market for mobiles } \\
\text { - Removal of excessive taxes } \\
\text { - Presence of established importers } \\
\text { - Awareness among affluent } \\
\text { consumers }\end{array}$ & $\begin{array}{l}\text { - Limited of demand/awareness } \\
\text { - High costs } \\
\text { - Telecom infrastructure still in infancy }\end{array}$ \\
\hline $\begin{array}{l}\text { Localisation } \\
\text { and adaptation }\end{array}$ & $\begin{array}{l}\text { - Regional integration and prospects } \\
\text { - Growing demand } \\
\text { - Saturated mobile markets elsewhere } \\
\text { - BoP adoption/diffusion schemes }\end{array}$ & $\begin{array}{l}\text { - High costs } \\
\text { - Limited awareness of potential } \\
\text { - Only small scale adaptation }\end{array}$ \\
\hline $\begin{array}{l}\text { Intense } \\
\text { competition }\end{array}$ & $\begin{array}{l}\text { - Growing BoP demand for } \\
\text { ownership } \\
\text { - VAT removal (and VAT lobby) } \\
\text { - Competition of Chinese firms } \\
\text { - BoP-embedded sellers and services }\end{array}$ & $\begin{array}{l}\text { - Costs of purchase for poorest consumers } \\
\text { - Quality of grey market phones } \\
\text { - Reliability of phones }\end{array}$ \\
\hline Standardisation & $\begin{array}{l}\text { - Anti-counterfeit rules } \\
\text { - Growing lobbying by formal } \\
\text { industry } \\
\text { - Lack of enforcement previously }\end{array}$ & $\begin{array}{l}\text { - Enforcement still small-scale } \\
\text { - Avoidance by firms } \\
\text { - Risk of broad brush regulation affecting } \\
\text { BoP consumers }\end{array}$ \\
\hline \multicolumn{3}{|c|}{ 2) Mobile money } \\
\hline Pilot & $\begin{array}{l}\text { - Donor funding } \\
\text { - Projects in similar field }\end{array}$ & $\begin{array}{l}\text { - Absence of regulation } \\
\text { - Little local ownership }\end{array}$ \\
\hline $\begin{array}{l}\text { Early } \\
\text { innovation }\end{array}$ & $\begin{array}{l}\text { - Presence of partners } \\
\text { - Financial regulation } \\
\text { - Established mobile user base }\end{array}$ & $\begin{array}{l}\text { - Lack of awareness/demand } \\
\text { - High start-up costs for infrastructure }\end{array}$ \\
\hline $\begin{array}{l}\text { Aggressive } \\
\text { growth }\end{array}$ & $\begin{array}{l}\text { - Service delivery innovation } \\
\text { - Growing demand/network effects } \\
\text { - Competition in mobile money } \\
\text { - Increasing local agents }\end{array}$ & $\begin{array}{l}\text { - Low agent profitability in BoP locations } \\
\text { - Limited mobile coverage/ownership in } \\
\text { BoP locations } \\
\text { - Structures of service limiting some } \\
\text { forms of inclusive innovation }\end{array}$ \\
\hline Standardisation & $\begin{array}{l}\text { - Activity within the innovation } \\
\text { system } \\
\text { - Strategy issues in the lead firm } \\
\text { - Regulation and enforcement }\end{array}$ & $\begin{array}{l}\text { - Reciprocal relations limiting change in } \\
\text { structure } \\
\text { - Poor understanding of processes } \\
\text { - Costs of change for agents }\end{array}$ \\
\hline $\begin{array}{l}\text { Functional } \\
\text { scaling }\end{array}$ & $\begin{array}{l}\text { - Saturation of markets } \\
\text { - Banking legislation } \\
\text { - Banking competition }\end{array}$ & $\begin{array}{l}\text { - Lack of BoP market for wider m-money } \\
\text { services } \\
\text { - Lack of demand for wider services } \\
\text { - Difficulty in creating wider services }\end{array}$ \\
\hline
\end{tabular}

Table 1: Summary of key drivers and barriers in Kenyan case studies 


\section{ANALYSIS}

In this analysis section, we follow the three-step process outlined earlier: first identifying the key factors whose failure or success determines the outcome of the inclusive innovation system; then analysing the policy measures which relate to those factors; and finally assessing the implications of any theory_practice gaps in policy.

\subsection{Trajectories and facilitators in innovating for low-income markets}

In both cases, one can see the shadow of the diffusion of innovation model. In the early stages, regulatory interventions - a mix of both addition and removal of regulations - are the foundations for each sub-sector: reducing risks, enabling market entry, signalling market existence. This enables development of, or access to, innovative technology which is taken by the "early adopters" (Rogers 1995): in developing countries, the more affluent users. However, the anticipated S-curve of diffusion does not immediately materialise because various barriers - including the relatively limited size of the "middle-of-the-pyramid" in a developing country - mean growth rates remain relatively low.

Over time, though, the innovations become adapted for the majority, low-income market. In early stages, there is evidence in both cases of context-specific adaptation of the innovations. However, successful adaptation does not immediately result in significant BoP market growth. Thus, while appropriate adaptive innovation is a necessary condition for expansion into such markets - both to produce appropriate technical applications and then to shape the socio-technical delivery and operation systems - it may not be a sufficient condition on its own for innovation systems to deliver at scale for low-income consumers.

The cases suggest that there are two other crucial conditions that played a role. Firstly competition, with increasing entrance of firms into the sector driving all players to push adapted innovations more aggressively and enter more marginal markets to maintain profits. Secondly, the ability for intermediaries to be part of the innovation system and be incrementally innovative. Once these three conditions are in place, there is evidence that a virtuous circle can form as shown in Figure 1. Intermediaries create local innovation, and in intense-enough markets reverse flows of innovation will occur in the system, with adaptations of intermediaries adopted and supported by some firms in the market, leading to further growth and more expansion of intermediaries. 


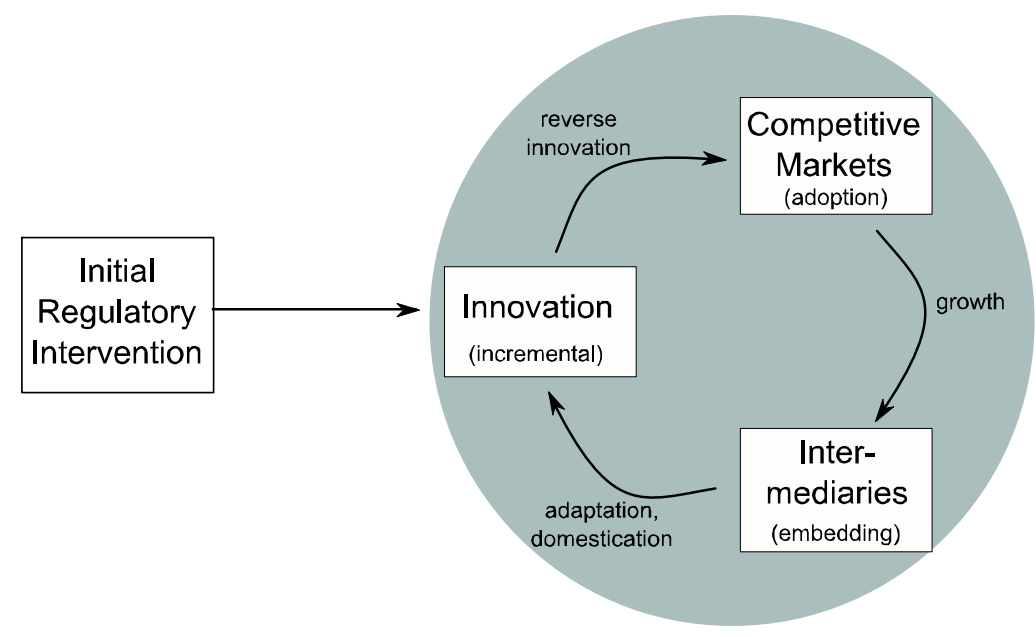

Figure 1: Core facilitators of inclusive innovation

\subsection{Policy and inclusive innovation facilitators}

In line with our mediated view of policy, and having identified key factors that have facilitated the inclusiveness of this innovation system, we now analyse the interaction of policy with those factors. We will move quickly over the initial regulatory interventions since they are themselves all policies, and since they had no focused pro-poor intent that would foster the specifically inclusive aspects of the innovation system, though they were a necessity for its existence.

Policy's clearest influence has been on competition. By simultaneously regulating and liberalising market entry, and regulating some aspects of mobile technologies, policy has ensured market entry and competition, which has been the core driver behind opening up of low-income markets. In mobile handset supply, VAT removal increased competition between different supply sources still further and helped open markets into rural areas. The financial guidelines issued in 2010 have likewise pushed Safaricom to try to connect its wider mmoney services into low-income markets.

In terms of the adaptive innovations required to reach such markets, policy has had a less direct effect. Relatively liberal trade policy has been a foundation for the technology imports that all adaptive innovations are built on, and aid policy has supported mobile phone demonstration and market articulation projects which in the long run have influenced the type of innovations undertaken, including the specific innovation that underpins M-Pesa. One can also attribute foundational roles to other generic policies: for example, the ability of local 
mobile sellers and m-money agents to innovate is only possible because government policies have created an appropriate educational, technical and security infrastructure. But equally notable is the potential "quintuple displacement" from the traditional concerns of government supply-side innovation policy, with its focus on core industrial R\&D. The inclusive innovations required for development and delivery to low-income groups are - particularly in the M-Pesa case - of services rather than products; adaptive and incremental rather than fundamental; located in multiple locations of small and medium enterprises embedded in poor communities rather than concentrated in a single facility; undertaken by "ordinary" entrepreneurs rather than trained experts; and continuous rather than discrete. Hence it may be preferable to apply the "innofusion" label. Not all the inclusive innovations share all these features, e.g. the initial development of M-Pesa, and handset innovation. Nonetheless, innovation policy is a "dog that did not bark" in these cases, raising questions not just of how such policy could be reoriented to a more inclusive role, but of the rationale and necessity for such a role.

Policy's role vis-à-vis the "innofusion" intermediaries has been even more diffuse, though one would look for policies that make intermediary roles attractive for entrepreneurs already embedded in poor communities, by increasing awareness or by expanding potential profits or by reducing start-up risks and costs. There is little of this in M-Pesa but for mobile handsets, some demand induction occurred early on, particularly via the shared phone schemes supported by the state as part of universal service and rural connectivity initiatives. This had a role in pushing demand for ownership among low-income communities, and giving insight into the level of risk for embedded entrepreneurs. There are also generic policies - for instance business start-up and operation regulation - which have had some effect; albeit mixed given the informal sector nature of some intermediaries.

Figure 2 presents an outline summary of some of the types of policy that have helped support inclusive innovation in this instance. 


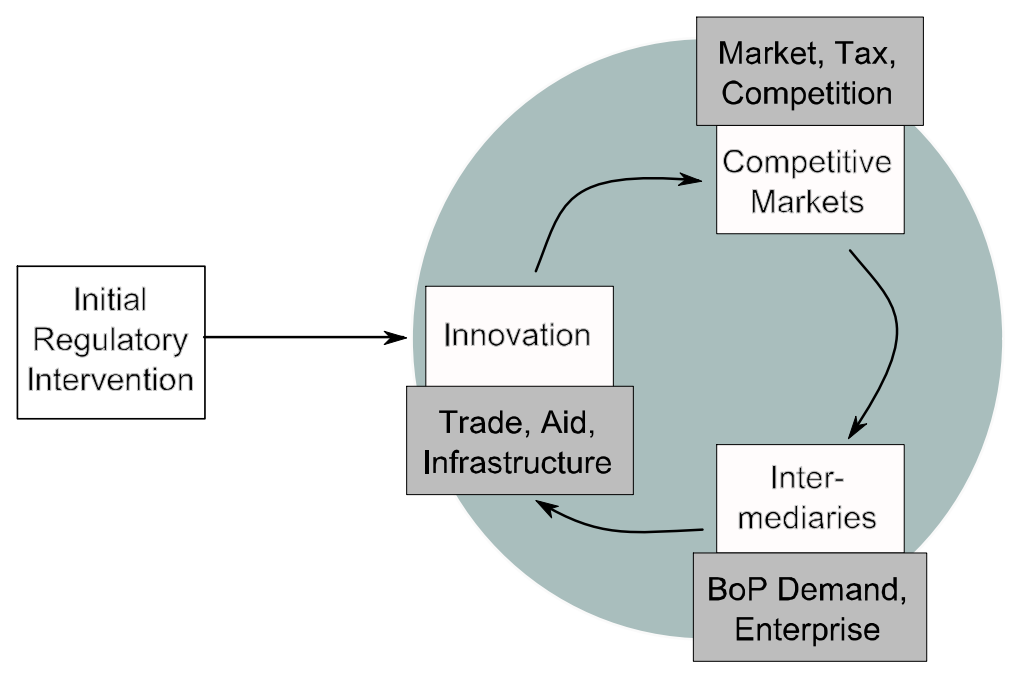

Figure 2: Policy for inclusive innovation facilitators

\subsection{Policy implementation issues}

As previously discussed, there is a variable gap between policy-as-made and policy-asimplemented; that gap having an impact on the inclusive innovation actors and facilitating factors. We can investigate that by going down to the micro-level of lived experiences of the innofusion intermediaries: the mobile handset sellers/repairers and mobile money agents who ensure these innovations can be accessed by base-of-the-pyramid consumers. Table 2 lists their main problems or concerns. 


\begin{tabular}{|c|c|}
\hline Problem/Concern & Explanation \\
\hline \multicolumn{2}{|c|}{ 1) Mobile handset intermediaries } \\
\hline \multicolumn{2}{|l|}{ Competition } \\
\hline $\begin{array}{l}\text { Finding and paying for } \\
\text { location }\end{array}$ & $\begin{array}{l}\text { The need to be located in a high volume location in order to attract high } \\
\text { customer, in hand with the need to pay 'goodwill': a one-off charge to } \\
\text { secure a good location }\end{array}$ \\
\hline $\begin{array}{l}\text { Local inspectors and } \\
\text { corruption }\end{array}$ & $\begin{array}{l}\text { Extracting bribes related to counterfeit, unlocking activity and business } \\
\text { licences }\end{array}$ \\
\hline Malfunctioning phones & Chinese phones often stop working, quickly creating problems \\
\hline $\begin{array}{l}\text { Cost of moving up/into } \\
\text { value chain }\end{array}$ & $\begin{array}{l}\text { High cost to start formal store, or in buying equipment in order to move } \\
\text { to a higher level of custom }\end{array}$ \\
\hline Learning needed & $\begin{array}{l}\text { Particularly among repairers, the need to keep up-to-date with the new } \\
\text { phones }\end{array}$ \\
\hline General security & Robberies, etc \\
\hline Unreliable staff & $\begin{array}{l}\text { Poor trust between owners and staff, to leave them running store or } \\
\text { holding any significant stock }\end{array}$ \\
\hline Credit relations & Often needed between sellers and suppliers \\
\hline \multicolumn{2}{|l|}{ 2) M-Pesa agents } \\
\hline Network congestion & $\begin{array}{l}\text { Recent network saturation means that at peak times service is } \\
\text { congested, customers have to wait }\end{array}$ \\
\hline $\begin{array}{l}\text { Crime: scams, fake money, } \\
\text { store robbery }\end{array}$ & Security related directly to weaknesses in the form of service \\
\hline Float problems & $\begin{array}{l}\text { Weaknesses in service making some agents regularly need to 'float } \\
\text { balance', requiring costly travel to local banks to get more float }\end{array}$ \\
\hline \multicolumn{2}{|l|}{ Competition } \\
\hline Supply chain complaints & Typically related to the relationship with dealers \\
\hline $\begin{array}{l}\text { Customers: congestion, } \\
\text { dissatisfied }\end{array}$ & $\begin{array}{l}\text { At closing time and during network problems, many customers waiting } \\
\text { around. Often become angry at delay }\end{array}$ \\
\hline $\begin{array}{l}\text { Security of transportation } \\
\text { of money }\end{array}$ & Relates to start of day and float balancing movements of cash \\
\hline \multicolumn{2}{|l|}{ Low profits } \\
\hline $\begin{array}{l}\text { Errors in customer use of } \\
\text { service }\end{array}$ & $\begin{array}{l}\text { Where customers type in numbers, they often get this wrong, leaving } \\
\text { agents to resolve }\end{array}$ \\
\hline
\end{tabular}

Table 2: Common problems of innovation intermediaries (in order of frequency) 
We will now investigate some of these in greater detail, to understand their relation to policy implementation ${ }^{3}$. We start with network congestion problems in the use of M-Pesa. This can be related back to the original regulatory policy drawn up at the time mobile operator licences were issued, which included rules on operator performance and service quality. But those rules had not been enforced: more than 12 years after licences were issued, the regulator was only just receiving the resources necessary to monitor service quality at the time of fieldwork. As a result, networks were based around legacy equipment and were overloaded at peak times. This had a somewhat "chilling" effect on innovation, since it restricted BoP market growth and diverted innovation system resources towards addressing this problem rather than towards other innovations.

Inclusive innovations were most obviously affected by policy implementation in terms of handset quality. Trade and telecommunications policies on paper allowed only officiallylicensed phones to be imported, and only quality-approved phones to be sold and connected to the network. But lack of enforcement ensured many grey-market phones got through which, as noted above, might have various "inclusive" innovative aspects that made them particularly suitable for BoP consumers. However, it also became apparent over time that alongside these positives were negative "innovations" within the handsets which meant many were of poor quality and caused problems: batteries and chargers would stop working, phones would break down if dropped or left in the sun, speakers and earpieces would break easily, and ability to connect to the network could be patchy. This undermined the inclusive nature of the innovations: richer clients would get good products and services, poorer ones would get the opposite. It also, again, diverted resources as one interviewed seller described:

"I used to sell China phones but I lost money because people would bring them back malfunctioning, and by the time I could go to the wholesaler in town the warranty was finished"

The mirror-image was also found: that good policy implementation could squeeze out negative service adaptations. To illustrate, some M-Pesa agents based in poor communities, tried to circumvent normal registration and operation rules. But there is relatively good

\footnotetext{
${ }^{3}$ Though we note there are lessons here for other aspects of inclusive innovation systems. For example, about appropriate levels of competition. At local level, there are dangers of unregulated over-competition between intermediaries reducing income and dampening innovation. At national level, lack of competition policy may see footnote 1 - cause one m-money service provider to dominate; a factor that might partly underlie some of the service issues noted.
} 
monitoring and enforcement of the regulatory requirements: one agent, for instance, was closed down for 14 days having been caught waiving ID requirements for customers; something which could ultimately undermine the trustworthiness of the payment system.

Poor enforcement of rules on the quality of innovation can be a problem in and of itself, but it may also lead to a snowballing of difficulties. One can argue, for example, that poor enforcement of earlier policies is a direct cause of the 2008 Anti-Counterfeit Act, with its much stronger remit and powers. If fully implemented - taking 2.3 million grey-market phones out of the system - it would be severely disruptive to the innovation system; extinguishing many intermediaries rather than allowing them to adapt, and destroying a large number of relationships within the system.

Policy implementation gaps related to markets and intermediaries tend to be interlinked. Here the notion of basic economic institutions is central (Altenburg 2009). Much of the growth of inclusive innovation can be connected to underlying good policy making and implementation related to basic institutions. Market entry has been eased through improving the ability of entrepreneurs to open bank accounts, and respondents reported that for them, starting a business is becoming more simple and inexpensive because of good policy and implementation in areas such as business licences (see also FSD Kenya 2009, Jacobs et al. 2007). For micro-enterprise intermediaries, awareness of business requirements, and more consistent implementation of rules relating to local trading and increasingly consistent enforcement in areas such as taxation have made it easier to set up and trade in a consistent manner, with those certainties enabling the focus for their innovations to be their core goods and services rather than survival.

Conversely, poor implementation of locational policies was causing difficulties. The 2005 Sessional Paper on Development of Micro and Small Enterprise mandated local authorities to provide spaces for MSEs. But this has barely been put into practice, leading to a spiralling of "goodwill" payments - a quasi-bribe, quasi-fee paid to the landlord or previous tenant of a business space; sometimes equivalent to six months' rent. This prices poorer entrepreneurs out of start-up, and so dampens the inclusivity of the overall innovation system.

Figure 3 summarises the main issues around implementation, with the evidence pointing to the importance of implementation. Inclusive innovation actors respond to signals - both the formal policy and also its actual implementation - and direct their innovatory behaviour 
accordingly. So underlying policy not only needs to be sound - which in this case it generally seems to be - but also consistently enforced. Without this, detrimental innovations may emerge, innovative capacities may have to be directed to other activities, and problems may snowball to the extent that eventual policy "cures" may be as damaging as the "disease".

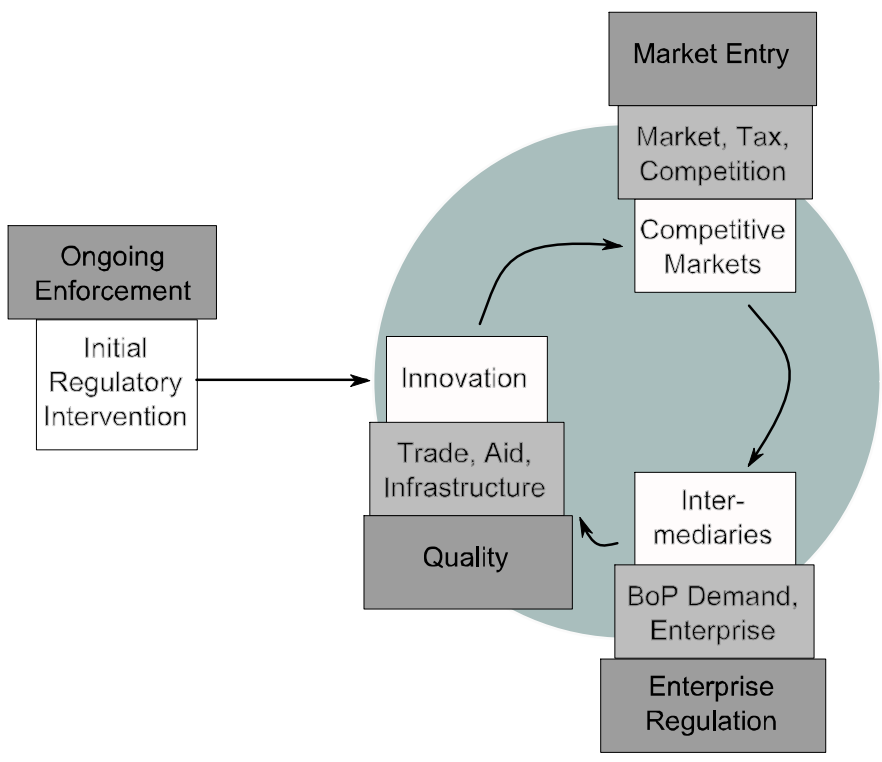

\section{Figure 3: Emergent implementation-related issues in inclusive innovation}

\section{CONCLUSIONS}

Alongside the growing interest in inclusive innovation, there has so far been relatively little work evidencing the policies that can support such innovation. This paper has set out to address that gap in knowledge, though limiting itself to just two successful case studies within one sector in one country, and defining inclusivity in terms of innovation impact - its development and diffusion to low-income consumers - rather than in terms of innovation processes.

The analytical approach followed had three stages.

First, the core purpose for policy was identified. Some BoP-targeted innovations fail to scale successfully (Anderson \& Billou 2007) but for those which do, this purpose relates not to extant market failures, but to key areas in which barriers have been overcome, as revealed by historical analysis of the innovation systems from start to date. Focusing specifically on the low-income segment, we argue that the inclusive innovation systems were built around a potential virtuous circle of pro-poor adaptive innovations, dynamic competition in markets, 
and innofusion intermediaries within poor communities, underpinned by initial policies that simultaneously regulated and de-regulated.

Second, the specific policies which supported the components of inclusive innovation were identified. These were drawn from a broad continuum of domains, running from what may be called sector-specific (e.g. removal of VAT on mobiles, rules on approved mobiles, m-money regulations) through sector-significant (e.g. the Anti-Counterfeit Act, and universal service initiatives) and sector-foundational (e.g. business/enterprise laws, and trade policy) to generic (policies on education, security, taxation, etc).

Two lacunae are notable. One is the absence from our narrative of anything that looks much like traditional innovation policy. Turning back to the policy domains identified in the earlier literature review, none of the typical supply-side interventions and few of the demand-side interventions are present, and the closest we get to IPR legislation is the belated AntiCounterfeit Act which has yet to be scalably enforced. Generic policies are present but they are, by definition, not innovation-specific. That is not to find no potential role for a reoriented innovation policy - one that engaged far more with BoP users, markets, intermediaries, suppliers, etc. - but that is a separate topic.

The other absence has been of specifically pro-poor policies. Again, there are odd exceptions like the rather poorly-implemented universal service initiative, but the policies outlined have largely been population-wide and income-blind. There are arguments about the political economy of policy making which go beyond the scope of this paper, but it may be that there is limited scope for pro-poor influences in the shaping of policy. It may therefore be fortunate that powerful private sector actors wanted to develop the BoP as a market, thus leading policies to cover the inclusive elements of the innovation system. As with the point above about innovation policy and again slipping from the descriptive to the prescriptive, it is easy to argue that policies could have a greater pro-poor orientation; aiming specifically at developing BoP markets, intermediaries and innovation.

Overall, it is only a slight exaggeration to conclude that the policies which have fostered inclusive innovation in these cases are not centrally about either inclusivity or innovation. At the least, this suggests a quite significant paradigm shift may be required from traditional views about pro-poor policies and innovation policies if inclusive innovation is to be purposely supported. 
Third, we analysed the role of policy implementation in inclusive innovation, finding that there was a lack of enforcement at times. We have not had space to explore the issue but linking to our earlier review - it is likely that this arises because of features common in developing countries including lack of resources, and the presence of informal institutional forces: norms and values that cause bureaucracies to deviate from their formal remit, and which also dominate when formal institutional rules do not penetrate. The space created by this implementation gap was colonised by inclusive innovations, but not all were beneficial for consumers; particularly undermining the quality of BoP-oriented goods and services. So greater freedoms - via either policy liberalisation or poor regulatory enforcement - may mean more inclusive innovation, but that can have a negative aspect since local innovators may look to adapt or configure an innovation in any way possible. The implementation gap also caused uncertainties and problems for intermediaries that diverted them from innovative activity. In general, then, shortfalls in policy implementation interfered with the "virtuous circle" of inclusive innovation: undermining trust in innovations, restraining the ability of intermediaries to adapt or to take risks such as embedding in more marginal areas, and skewing markets unfavourably to those willing to circumvent the law.

In summary, putting these three analytical elements together produced a policy map for inclusive innovation, reproduced in Figure 4 with all aspects highlighted equally.

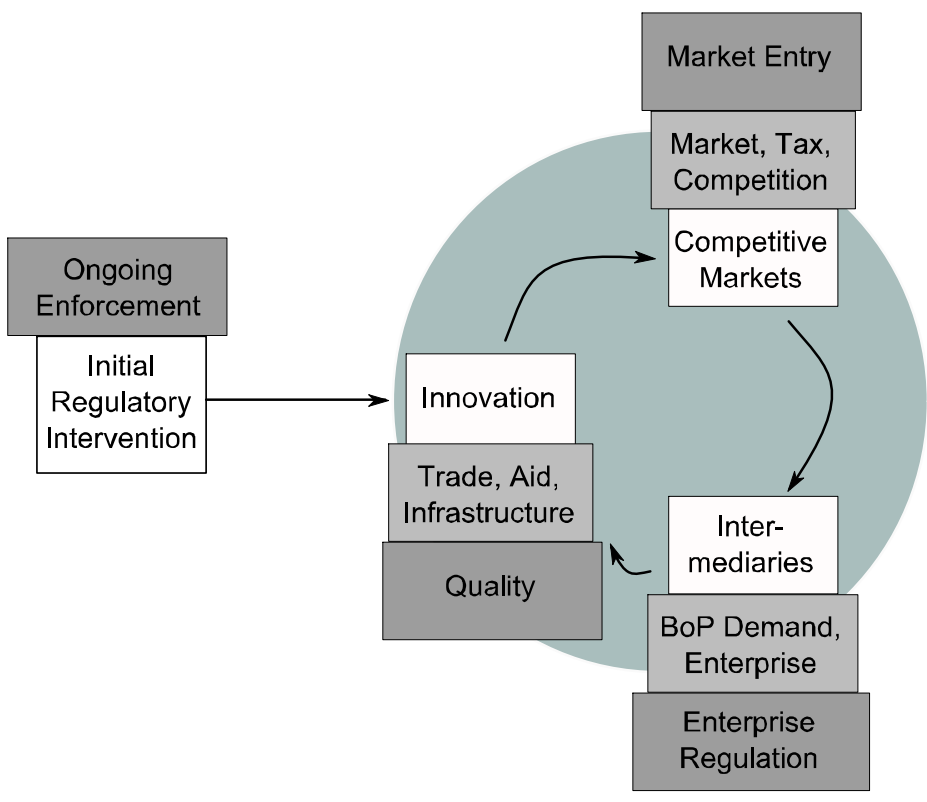

Figure 4: Policy map for inclusive innovation 
We have therefore seen policy as connecting to a more complex and uneven picture than is typically described in systems of innovation. It includes multiple domains and levels of policy makers and implementers, potentially non-coherent policy from multiple actors, and complex institutional terrains. Thus, in line with other work, we critique the simplistic idea of a single, monolithic policy maker. Rather, we see inclusive innovation policy as part of a "policy mix" in terms of alignment, complexity and implementation (Flanagan et al. 2011).

To repeat, this is drawn from a very narrow base, and Figure 4 may just be seen as a sensitising framework that subsequent studies in other sectors will need to modify. We must be similar cautious about recommendations. We have shown, though, that there is both a rationale and role for policy in supporting inclusive innovation, and that policy implementation must also be taken into account. In contrast to market-oriented analyses, the mobile sector cases show that policy making is not only already present but that policy choices have had a significant role in driving innovations towards poor consumers, and in establishing inclusive innovation systems. Inclusive innovation is thus already a domain of active policy making.

Where policy is effective in the first place, then its enforcement can help shape the direction of inclusive innovation towards more socially-beneficial outcomes. For this to happen, there must be a clear sense of where the inclusive innovation system is failing in terms of the innovations it allows or produces; development of appropriate policy to address those failures; and effective implementation of those policies. Some of the policy domains will be those seen in the Kenyan case, but future research may throw up other domains and also explore further the potential for policies that deliberately target the processes and products of inclusive innovation.

\section{REFERENCES}

Altenburg, T. (2009) Building Inclusive Innovation Systems in Developing Countries: Challenges for IS Research. In: B. A. Lundvall, K. J. Joseph, \& C. Chaminade eds. Handbook on Innovation Systems and Developing Countries: Building Domestic Capabilities in a Global Context. Edward Elgar, Cheltenham, UK, pp. 33-57.

Anderson, J. (2010) M-Banking in Developing Markets: Competitive and Regulatory Implications. info, 12(1), pp. 18-25.

Anderson, J. \& Billou, N. (2007) Serving the World's Poor: Innovation at the Base of the Economic Pyramid. Journal of Business Strategy, 28(2), pp. 14-21.

Arocena, R. \& Sutz, J. (2000) Looking at National Systems of Innovation from the South. Industry \& Innovation, 7(1), pp. 55-75. 
Ashford, N.A., Ayers, C. \& Stone, R.F. (1985) Using Regulation to Change the Market for Innovation. Harvard Environmental Law Review, 9, pp. 419-466.

Bell, M. \& Pavitt, K. (1993) Technological Accumulation and Industrial Growth: Contrasts Between Developed and Developing Countries. Industrial and Corporate Change, 2(1), pp. 157-210.

Berdegué, J.A. (2005) Pro-Poor Innovation Systems. Background Paper, IFAD, Rome.

Bergek, A., Jacobsson, S., Carlsson, B., et al. (2008) Analyzing the Functional Dynamics of Technological Innovation Systems: A Scheme of Analysis. Research Policy, 37(3), pp. 407-429.

CBK (2010) Guideline on Agent Banking, Government Guideline, CBK/PG/15, Central Bank of Kenya, Nairobi, Kenya.

CCK (2011) CCK Extends Deadline for Switch Off of Counterfeit Mobile Handsets. Communications Commission of Kenya. Available from: http://www.cck.go.ke/news/2011/counterfeit_phones.html [Accessed 2 June 2012].

CCK (2012) Quarterly Sector Statistics Report: $2^{\text {nd }}$ Quarter October-December 2011-2012. Communications Commission of Kenya, Nairobi, Kenya.

Chaminade, C. \& Edquist, C. (2010) Rationales for Public Policy Intervention in the Innovation Process: A Systems of Innovation Approach. In: S. Kuhlmann, P. Shapira \& R. Smits eds. Innovation Policy - Theory and Practice. Edward Elgar, Cheltenham, UK, pp. 83-97.

Cozzens, S. \& Sutz, J. (2012) Innovation in Informal Settings: A Research Agenda. IDRC, Ottawa, Canada.

Edler, J. (2010) Demand-based Innovation Policy. In: R.E. Smits, S. Kuhlmann, \& P. Shapira eds. The Theory and Practice of Innovation Policy: An International Research Handbook. Edward Elgar, Cheltenham, UK, pp. 275-302.

Edquist, C. (1997) Systems of Innovation Technologies, Institutions and Organisations. Pinter, London, UK.

Edquist, C. \& Hommen, L. (1999) Systems of Innovation: Theory and Policy for the Demand Side. Technology in Society, 21(1), pp. 63-79.

Flanagan, K., Uyarra, E. \& Laranja, M. (2011) Reconceptualising the "Policy Mix" for Innovation. Research Policy, 40(5), pp. 702-713.

Fleck, J. (1993) Innofusion: Feedback in the Innovation Process, in F.A. Stowell, D. West \& J.G. Howell eds. Systems Science. Plenum Press, New York, pp.169-174.

FSD Kenya (2009) FinAccess National Survey 2009: Dynamics of Kenya's Changing Financial Landscape, Financial Sector Deepening Kenya, Nairobi, Kenya.

GSMA (2011) Mobile Telephony and Taxation in Kenya 2011, GSM Association, London, UK.

Jack, W. \& Suri, T. (2010) The Economics of M-Pesa: An Update, MIT Sloan, Boston, MA.

Jacobs, S., Ladegaard, P. \& Musau, B. (2007) Kenya's Radical Licensing Reforms, 2005-2007: Design, Results, and Lessons Learned. Paper presented at: Africa Regional Consultative Conference, Accra, Ghana, 5-7 Nov.

Johnson, B.H. \& Edquist, C. (1995) Institutions and Organisations in Systems of Innovation. In: C. Edquist ed. Systems of Innovation Technologies, Institutions and Organisation. Pinter, London, UK, pp. 41-63.

Kraemer-Mbula, E. \& Wamae, W. (2010) The Relevance of Innovation Systems to Developing Countries. In: E. Kraemer-Mbula \& W. Wamae eds. Innovation and the Development Agenda. OECD, Paris, pp. 39-64..

London, T. (2009) Business Model R\&D for New Market Entry, Working Paper, William Davidson Institute, University of Michigan, Ann Arbor, MI.

London, T. \& Hart, S.L. (2004) Reinventing Strategies for Emerging Markets: Beyond the Transnational Model. Journal of International Business Studies, 35(5), pp. 350-370.

Lorentzen, J. \& Mohamed, R. (2009) Where are the Poor in Innovation Studies? Paper presented at: Globelics 2009, 7th International Conference, Dakar, Senegal, 6-8 Oct.

Lundvall, B.A. (1992) National Systems of Innovation: Toward a Theory of Innovation and Interactive Learning. Pinter, London, UK.

Lundvall, B.A., Joseph, K. \& Chaminade, C. (2009) Handbook on Innovation Systems and Developing Countries: Building Domestic Capabilities in a Global Context. Edward Elgar, Cheltenham, UK. 
McCormick, D. \& Oyelaran-Oyeyinka, B. (2007) Introduction: Clusters and Innovation Systems in Africa. In: D. McCormick \& B. Oyelaran-Oyeyinka eds. Industrial Clusters and Innovation Systems in Africa. United Nations University Press, New York, NY, pp. 1-26.

Miles, M.B. \& Huberman, A.M. (1994) Qualitative Data Analysis: An Expanded Sourcebook. Sage, London, UK.

OECD (2011) Demand-side Innovation Policies. OECD, Paris.

Prahalad, C.K. (2009) The Fortune at the Bottom of the Pyramid: Eradicating Poverty Through Profits. 5th Anniversary ed. Wharton School Publishing, Philadelphia, PA.

Rogers, E.M. (1995) Diffusion of Innovations. 4th ed. Free Press, New York, NY.

Safaricom (2011) M-PESA Customer and Agent Numbers [Online]. Available from: http://www.safaricom.co.ke/index.php?id=1073 [Accessed 2 June 2012].

Scott, W.R. (2001) Institutions and Organizations. Sage, London, UK.

Srinivas, S. \& Sutz, J. (2008) Developing Countries and Innovation: Searching for a New Analytical Approach. Technology in Society, 30(2), pp. 129-140.

Williams, R., Stewart, J. \& Slack, R. (2005) Social Learning in Technological Innovation: Experimenting with Information and Communication Technologies. Edward Elgar, Cheltenham, UK.

World Bank (2010) Kenya Economic Update: Kenya at the Tipping Point?, World Bank, Nairobi, Kenya. 